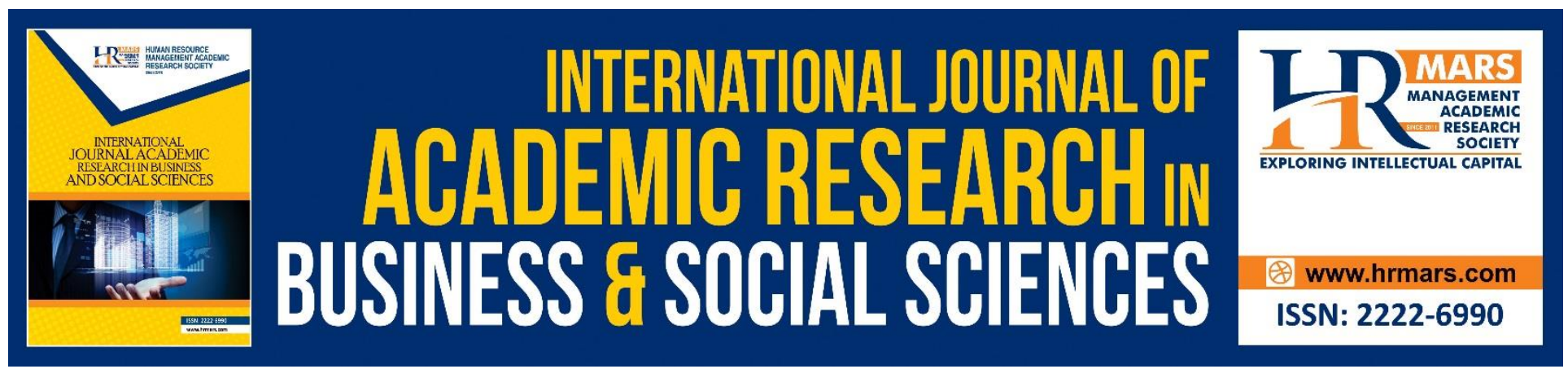

\title{
Building a Corporate Competitiveness through Corporate Social Responsibility Drives
}

F. O. Uchehara

To Link this Article: http://dx.doi.org/10.6007/IJARBSS/v9-i5/5903

DOI: $10.6007 /$ IJARBSS/v9-i5/5903

Received: 10 March 2019, Revised: 27 April 2019, Accepted: 02 May 2019

Published Online: 22 May 2019

In-Text Citation: (Uchehara, 2019)

To Cite this Article: Uchehara, F. O. (2019). Building a Corporate Competitiveness through Corporate Social Responsibility Drives. International Journal of Academic Research Business and Social Sciences, 9(5), 531-541.

Copyright: (C) 2019 The Author(s)

Published by Human Resource Management Academic Research Society (www.hrmars.com)

This article is published under the Creative Commons Attribution (CC BY 4.0) license. Anyone may reproduce, distribute, translate and create derivative works of this article (for both commercial and non-commercial purposes), subject to full attribution to the original publication and authors. The full terms of this license may be seen at: http://creativecommons.org/licences/by/4.0/legalcode

Vol. 9, No. 5, 2019, Pg. 531 - 541

http://hrmars.com/index.php/pages/detail/IJARBSS

JOURNAL HOMEPAGE

Full Terms \& Conditions of access and use can be found at http://hrmars.com/index.php/pages/detail/publication-ethics 


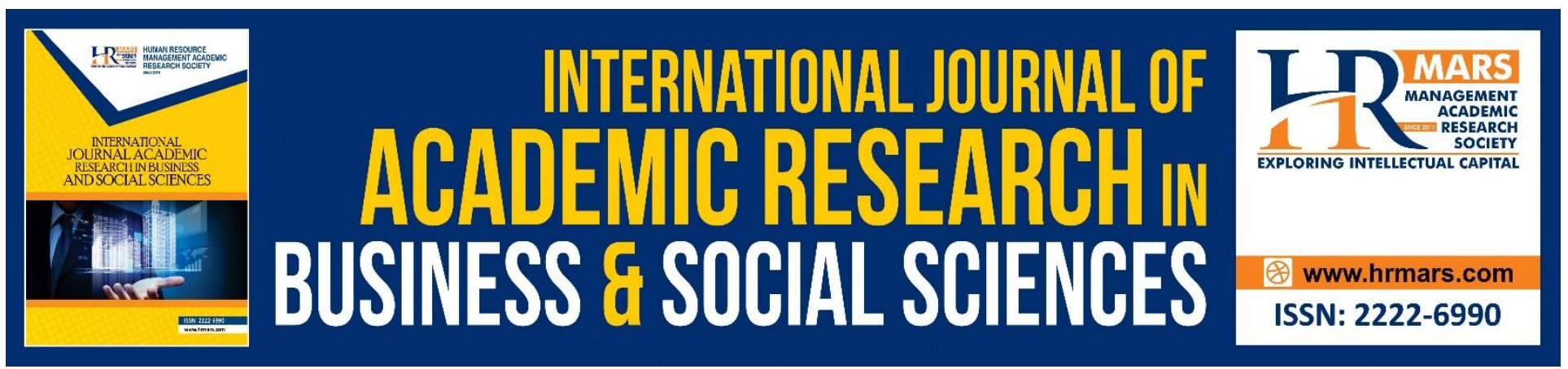

\title{
Building a Corporate Competitiveness through Corporate Social Responsibility Drives
}

\author{
F. O. Uchehara (Pd.D) \\ Department of Business Administration, Chukwuemeka Odumegwu Ojukwu University, Anambra \\ State \\ Email: fo.uchehara@coou.edu.ng
}

\begin{abstract}
The essence of most business organisation is to remain in business. Competitiveness is one key strategy to business survival. As firms has to garner the ability to sell products that meet demand requirements (price, quality, quantity) and, at the same time, ensure profits over time that enable the firm to thrive; this study aims to examine the role corporate social responsibility (CSR) in building corporate competitiveness for firms in the consumer goods sector in Nigeria from a panel data obtained from 12 firms within the period of 2015 to 2017. Two models representing Return on Investment and Return on Sales were developed and regressed on CSR investment variable. Results from pooled simple OLS regression analyses revealed that CSR had positive and significant effects on firm return on sales (ROS) and return investment (ROI). It thus conclude that CSR is a veritable management strategy to enhancing corporate competitiveness of business in Nigeria. The study therefore recommended that firms should incorporate CSR obligations into its corporate strategic plans.
\end{abstract}

Keywords: Building, Corporate competitiveness, Corporate social responsibility, Drives

\section{Introduction}

The place of corporate social responsibility (CSR) on organisational success and competitiveness has remained a much debated and object of academic criticism. CSR is a concept whereby firms commit to improve their environmental and social performance beyond legal obligations. It is a commitment to improve the wellbeing of a community through discretionary business practices and contributions of corporate resources (Charkraborty, 2010; Nasieku, Togun \& Olubunmi, 2014). It is the commitment of business to contribute to sustainable economic development, working with employees, their families, the local community and society at large to improve quality of life, in ways that are both good for business and good for development (Korkchi \& Rombaut, 2006; Nasieku, Togun \& Olubunmi, 2014). 
Historically, McPeak and Oianwen (2011) acknowledges that the emphasis on corporate social responsibility has been visible since 1984 when many multinational firms were formed and the term - stakeholders clearly referred to those individuals and organizations that the firm's activities impacted (Freeman, 1984). Corporate Social Responsibility (CSR) activities are no longer only charitable events but tools for boosting positive image of the company, employee and customer satisfaction and organizational profitability. Islam, (2012) confirmed that the concept of business has changed from profit making activities to social welfare activities where businesses are not only responsible to its shareholders but also to all of its stakeholders. The main force that drives companies to adopt corporate social responsibility is CSR's financial benefits (Rapti \& Medda, 2012). Nicolau (2008) defined socially responsible companies as those which in profit-making operational decisions, considers the full scope of environmental impact and balances the needs of stakeholders.

Researchers like Stanwick and Stanwick (1998) and Maignan and Ferrel (2004) have suggested that corporations should perform CSR activities and to communicate these activities to their customers, public, government. Corporate social responsibility increases employee commitment level with the organization because CSR activities include welfare of the employees and their families (Ali, Rehman, Yilmaz, Nazir and Ali, 2010). Dawkins (2004) stated that when an organization contributes towards social welfare, it enhance commitment level of existing customers and attracts the motivated potential employees. Brammer, Millington and Rayton (2007) stated when a company has CSR initiatives; employees are more proud of and committed to the organization. According to Stawiski et al. (2010) organization should involve their employees in decision making regarding which actions should be undertaken relating to community, environment and employees themselves so that organization can get maximum benefits of CSR. Employees will be motivated by organization's CSR activities and ultimately organizational performance will increase. This study is motivated by the fact that as the global business world is getting more competitive by the day due to globalization and technological change, only the effective will continue to maintain the top position and gain competitive advantage.

Competitiveness is likened to firm's ability to face competition and to be successful when facing competition. Competitiveness would then be the ability to sell products that meet demand requirements (price, quality, quantity) and, at the same time, ensure profits over time that enable the firm to thrive. Competition may be within domestic markets (in which case firms, or sectors, in the same country are compared with each other) or international (in this case, comparisons are made between countries). Competitiveness is therefore a relative measure. It is, however, a broad concept and there is no definitive agreement on how to measure it precisely. However, there is more or less a consensus on which measures could be used to assess competitiveness. There has been controversies on whether firms should be responsible to both the shareholders and the environment where they operate. Theories exist to refute as well as agree that firms should be socially responsible.

Competiveness is one core benchmark for assuring that a firm remains a going concern in modern business environment. Competiveness goes beyond having a quality product at good prices and covering the market size adequately, a firm must make sufficient profit to satisfy investors' rate of 
INTERNATIONAL JOURNAL OF ACADEMIC RESEARCH IN BUSINESS AND SOCIAL SCIENCES Vol. 9, No. 5, May, 2019, E-ISSN: 2222-6990 @ 2019 HRMARS

return and social obligations. The extent to which firms remain competiveness can be captured by the firm returns on investment. The main objective of the study is to establish the effect of corporate social responsibility on corporate competiveness of quoted firms in Nigeria. The specific objectives are:

1. To assess if increase in Corporate Social Responsibility activities will lead to increase in Return on investment.

2. To examine if companies that undertake more Corporate Social Responsibility activities will experience increased Return on Sales.

\section{Review of Related Literature Conceptual Framework}

The philosophy behind the act of Corporate Social Responsibility (CSR) for organizations is that firms have to contribute to the development of its host communities. Leaving an environment better than one meets it demands that we assist in providing assistances to better the lives of people and state of things in our immediate environment. Thus, the concept of CSR is being reactive to the needs of the community (Deetz, 2003). It is "Paths of progress which meet the needs and aspirations of the present generation without compromising the ability of future generations to meet their needs." (Brundtland, 1987). Thus, CSR is an obligation, beyond that required by the law and economics, for a firm to pursue long term goals that are good for society (Folajin, Ibitoye, \& Dunsin, 2014). This connotes that organizations in addition to performing their legal duties as artificial entities, must identify with its host communities in order to better its environment, create value for society, treat its employees fairly. Succinctly put, Maigan and Ferrell, (2004) described corporate social responsibility as an instrument to increase firms' legitimacy in the eyes of their stakeholders and to develop positive social responsibility images to burnish their reputations. Danko, Goldberg, Goldberg and Grant (2008:42) summarized the four (4) elements of CSR to include: "moral obligation" or duty to act responsibly as a good corporate citizen; "sustainability" generally defined as meeting the needs of the present without compromising the ability of future generations to meet their own needs; the company's needs for "license to operate" as implicit or explicit approval from the host government, communities and stakeholders; and the "reputation" where CSR firms aimed to improve images, strengthen brands and increase values.

From the above definitions, it can be said that CSR involves all the corporate activities aimed at being at peace with the society and the environmental where it operates. It includes acts to correct and or prevent environmental hazards, improve the welfare for the society and make good image.

\section{Theoretical Framework}

The theoretical framework is hinged on the Stakeholders theory otherwise known as the classical economic view. The Stakeholder Theory holds that business organizations must play an active social role in the society in which they operate. Freeman (1984), one of the advocates of stakeholder theory, presented a more positive view of managers' support of CSR. He asserts that managers must satisfy a variety of constituents (e.g. investors and shareholders, employees, customers, suppliers, government and local community organizations) who can influence firm outcomes. According to this view, it is not sufficient for managers to focus exclusively on the needs of stockholders, or the owners 
INTERNATIONAL JOURNAL OF ACADEMIC RESEARCH IN BUSINESS AND SOCIAL SCIENCES Vol. 9, No. 5, May, 2019, E-ISSN: 2222-6990 @ 2019 HRMARS

of the corporation. Stakeholder theory implies that it can be beneficial for the firm to engage in certain Corporate Social Responsibility activities that non-financial stakeholders perceive to be important, otherwise, these groups might withdraw their support (Ojo, 2008).

The most prevalent form of Corporate Social Responsibility under the shareholder theory is to do everything possible, within the confines of the law, to maximize shareholder wealth. A company's sole responsibility is to generate profits and increase the value of its shares. Social activities are only carried out if stipulated by law or if the activity contributes to increasing share value. Wealth creation is part of a company's social responsibility, but not the only one (Fauzi, 2008). Here the challenge is to turn Corporate Social Responsibility into a business opportunity. Compliance with the law is limited. Companies can follow the letter of the law yet still exploit workers, consumers and resources. To achieve sustainable economic success, executives need to take account of the interests of their employees, customers, distributors and other stakeholders, (Melé 2008). The logic being implied by this approach is that previous levels of profit determine or influence subsequent corporate social performance and that the relationship is a positive one.

\section{Empirical Framework}

Studies that show a link between CSR and competitive advantage is available in literature. In the work of Porter and Kramer (2006) expressed an empirical opinion that there is a link between CSR and competitive advantage, despite that they were not able to clearly explain how CSR affects competitive advantage. Battaglia, Testa, Bianchi , Iraldo and Frey (2014) in their study, analyses the link between the adoption of corporate social responsibility (CSR) and competitiveness performance among 213 small and medium enterprises operating in the fashion industry in Italy and France. A correlation analysis between competitiveness variables and the CSR practice adopted showed a significant correlation with regard to the innovation process, both from the technical and the organizational point of view, and the intangible performances. On the other hand, another competitiveness macro-category, which is the market performance (measured as demand trend, turnover and business attraction), presents deceptive results, although a positive correlation with the adoption of market-oriented CSR practice emerges. However, in Ghana Asamoah (2013) used a survey design to examine the perceived influence of the practice of CSR in achieving competitive advantage among all the 6 Mobile Telecommunication companies operating in Ghana. The study found that the performance of the companies CSR practices was high in the areas of community support, environmental issues, and ethics; for reasons including that they aim to enhance the reputation of the company, for positive image and branding of the company, to gain some competitive advantages, to improve business performance etc. The study however found that the companies gained to moderated extent competitive advantage by engaging in CSR.

Abogun, Fagbemi, and Uwuigbe (2013) examined the relations between CSR expenditure on firm's performance and firm values. Data were sourced from the annual reports of quoted firms on the Nigerian Stock Market using exploratory research design. The Pearson product moment correlation coefficient and OLS method of regression analysis were used to estimate the relationship in the variables of study. Return on Asset (ROA) and Return on Equity ROE) were used to proxy firm performance while Earnings per Share (EPS) and Dividend per Share (DPS) were used to proxy firm value. The study revealed the CSR has impact on ROA, ROE, DPS and EPS at varying degrees. The study 
INTERNATIONAL JOURNAL OF ACADEMIC RESEARCH IN BUSINESS AND SOCIAL SCIENCES Vol. 9, No. 5, May, 2019, E-ISSN: 2222-6990 @ 2019 HRMARS

therefore conclude that there is positive relationship between CSR and firm performance and firm value.

Akindele (2011) adopted a survey design using ex-post facto type, with officials drawn from 4 randomly selected banks type in Nigeria in carrying out a study on corporate social responsibility: An organizational tool for survival in Nigeria. The general objective of the study is to examine the extent and role of the retail banking industries in corporate social responsibilities practices to help achieve sustainable growth and development in the local communities. The data for the study was analyzed using both descriptive and inferential statistics, while predictions and decisions based on sample data were determined using Analysis of variance (ANOVA). It was found that there is a significant relationship between bank profitability and CSR practices.

Another study supporting positive relationship between corporate social responsibility and business competitiveness is Shehu (2013) which examined the influence of corporate social responsibility on profit after tax of some selected deposit money banks in Nigeria. Based on the objective of assessing the influence of CSR on PAT, the study used secondary source of data from annual reports of some selected banks, and through fact books of Nigerian Stock Exchange (NSE) for the period of the study (2006-2010) by means of content analysis. The study used regression and correlational analysis in interpreting the result and found that there is weak positive relationship between CSR and PAT significant at $5 \%$.

In the same vein, Eze and Okoye (2013) determined the effect of corporate social responsibility on the performance of Nigerian deposit money banks. The study adopted descriptive survey design in carrying out the study. The study reveals that Social responsibility has a great impact on the society by adding to the infrastructures and development of the society. It also conclude that a company has to give back to the society in which it operates, clean up all forms of pollution it has caused in its course of operation and also provide infrastructural facilities to the society as a way of giving back and developing the society.

Again, Odetayo, Adeyemi and Sajuyigbe (2014) investigated the effect of corporate social responsibility and profitability of Nigerian banks. To achieve the objectives of this study, data were collected from annual reports of sampled six banks, for the period of 10 years $(2003-2012)$. Simple regression analysis was employed as a statistical technique to analyse data collected using STATA 11. The regression results revealed that there is a significant relationship between expenditure on corporate social responsibility and profitability of Nigerian Banks. The study concludes that Nigerian banks recognized the importance of corporate social responsibility for sustainable development and they are performing their obligation to the society.

Malik, Ali and Ishfaq (2015) also from Pakistan, examined the impact of CSR activities and organizational performance in presence of organizational culture. This was an exploratory research based on primary and secondary data. The primary data of employees of banks collected while secondary data were collected from articles, reports and website of the corporation. The data were analysed using correlation, regression and analysis of variance by SPSS version 16 . The study found relationship between awareness of corporate social responsibility activities and organizational performance.

However, Folajin, Ibitoye, and Dunsin (2014) investigated the impact of Corporate Social Responsibility on bank profitability with particular reference to United Bank for Africa (UBA) Plc. The 
study used annual reports of United Bank for Africa (UBA) Plc. Data used include corporate social responsibility expenditure and profit after tax for the period of 2006-2012. Data relating to cost/investment/expenditure as the case may be for the bank on corporate social responsibility and profitability was used to construct ordinary least square (OLS) model of regression to which was analyzed using SPSS. Result showed that Corporate Social Responsibility spending has short term inverse effect on Net Profit but in the long run it will provide better returns.

From these empirical reviews, there is still controversies on the link between CSR and competitiveness/organisation performance.

\section{Methodology}

\section{Design and Data}

The study adopted the ex-post facto research design to satisfy the fact that the researcher data for the study already existed in the Annual Accounts of the selected companies and the researcher do not intend to manipulate the data. Twelve quoted Nigerian firms in the consumer goods sector are purposively selected for the study. The time frame covering a 3-year period (2015 to 2017) for twelve firms forms a panel of 36 audited annual accounts employed to examine the effect of corporate social responsibility on firm competiveness.

\section{Model Specification}

Two simple regression models were developed to address the two subjective outlined. Following the ideology in the work of Adeyemi (2014), the models were developed such that Corporate Social Responsibility as independent variable is regressed on profitability indices as deponent variable. Thus the functional relationship proposed for the two models are as follows:

$$
\begin{aligned}
& \text { ROI }=\beta_{0}+\beta_{1} \text { CSR }_{i t}+e_{i t} \\
& \text { ROS }=\beta_{0}+\beta_{1} \text { CSR }_{i t}+e_{i t}
\end{aligned}
$$

Where:

Corporate Social Responsibility expenditure (CSR) is represented by the log form of the total amount invested in CSR; Return on Investment (ROI) is measured as the proportion of profit after tax to issued share capital, while Return on Sales (ROS) is a dependent variable for hypothesis three. Return on sales measured as the proportion of profit after tax to the total sales. However, $\beta_{0}$ is the constant in the model while $\beta_{1}$ is the coefficient of the independent variable that explained the relationship with firm competitiveness.

\section{Method of Data Analyses}

Descriptive statistics and inferential statistical techniques were used to analyze the data. Multivariate regression Model based on Cross sectional pooled data from the annual reports and other financial statements. Pooled panel data analysis, also called the constant coefficients model is one where both intercepts and slopes are constant, where the cross section firm data and time series data are pooled together in a single column assuming that there is no significant cross section or temporal effects (Gujarati, 2003). 
INTERNATIONAL JOURNAL OF ACADEMIC RESEARCH IN BUSINESS AND SOCIAL SCIENCES

Vol. 9, No. 5, May, 2019, E-ISSN: 2222-6990 @ 2019 HRMARS

\section{Results and Discussion}

Presentation of Results

Table 2: Result of the Relationship between CRS and Corporate Competiveness

\begin{tabular}{|c|c|c|c|c|c|c|c|c|c|c|}
\hline & \multicolumn{5}{|c|}{ Model 1: ROI } & \multicolumn{5}{|c|}{ Model 2: ROS } \\
\hline \multirow[t]{2}{*}{ Model } & \multicolumn{2}{|c|}{$\begin{array}{l}\text { Unstandardiz } \\
\text { ed } \\
\text { Coefficients }\end{array}$} & \multirow{2}{*}{\begin{tabular}{|c|}
$\begin{array}{c}\text { Standar } \\
\text { dized } \\
\text { Coefficie } \\
\text { nts }\end{array}$ \\
Beta
\end{tabular}} & \multirow[t]{2}{*}{$\mathrm{T}$} & \multirow[t]{2}{*}{ Sig. } & \multicolumn{2}{|c|}{$\begin{array}{l}\text { Unstandardized } \\
\text { Coefficients }\end{array}$} & $\begin{array}{c}\text { Standa } \\
\text { rdized } \\
\text { Coeffic } \\
\text { ients }\end{array}$ & \multirow[t]{2}{*}{$\mathrm{t}$} & \multirow[t]{2}{*}{ Sig. } \\
\hline & B & $\begin{array}{l}\text { Std. } \\
\text { Error }\end{array}$ & & & & B & $\begin{array}{l}\text { Std. } \\
\text { Error }\end{array}$ & Beta & & \\
\hline (Constant) & 2.45 & 87.05 & & -18.42 & .004 & 27.92 & 17.85 & & $\begin{array}{r}32.05 \\
8\end{array}$ & .014 \\
\hline CSR & 11.44 & 2.46 & .416 & 9.988 & .035 & 84.63 & $\begin{array}{r}410.5 \\
8 \\
\end{array}$ & .028 & $\begin{array}{r}34.16 \\
1 \\
\end{array}$ & 0.003 \\
\hline & \multicolumn{5}{|c|}{$\begin{array}{l}\mathrm{R}=.835 \\
\mathrm{R} \text { Square }=.7913 \\
\text { Durbin-Watson }=1.949 \\
\text { F-value }=11.9123 \text { (prob. }\end{array}$} & \multicolumn{5}{|c|}{$\begin{array}{l}R=.728 \\
R \text { Square }=.641 \\
\text { Durbin-Watson }=1.719 \\
\text { F-value }=5.837 \text { (prob. }=0.023)\end{array}$} \\
\hline
\end{tabular}

a. Dependent Variable: ROI, ROS

b. Predictors: (Constant), CSR

\section{Corporate Social Responsibility Investment and Return on Investment}

The result on Model 1 showed the relationship between corporate social responsibility investment and return on investment. The coefficient of the correlation (R) with value of 0.835 indicates a strong positive correlation between CSR and ROI suggesting that investment CRS enhances return on investment by about $84 \%$. The result of the coefficient of determination ( $R$ Square $=0.7913$ ) reveal that about $79 \%$ of factoring driving return on investment can be explained corporate social responsibility investment indicating that CSR is a veritable corporate strategy to enhancing competiveness as proxied by rerun on investment. The F-value of 11.9123 (prob. $=.007$ ) means that CSR has a statistically significant effect on firm competitions (ROI). Furthermore, the coefficient of the regression (11.44) with p.value as .035 above 0.5 level of significance reveal a significant positive relationship between CSR and ROI.

\section{Corporate Social Responsibility Investment and Return on Sales}

Level of sales and investment on corporate social responsibility is subjected to OLS regression technique as shown on Model 2. The result from the coefficient of the correlation is 0.728 reveal a strong positive correlation between CSR and ROS. This implies that increased corporate social responsibility investment can lead to about $73 \%$ rise in sales. This is supported by the coefficient of determination value of 0.641 which indicate that about $64 \%$ of variations in sales can be explained 
INTERNATIONAL JOURNAL OF ACADEMIC RESEARCH IN BUSINESS AND SOCIAL SCIENCES Vol. 9, No. 5, May, 2019, E-ISSN: 2222-6990 @ 2019 HRMARS

by CSR investment. The F-statistics (Value $=5.837$, prob. $=0.023$ ) which is statistically significant at 0.05 level, reveal that CSR has a significant effect on ROS.

The coefficient of the regression (84.63) with t-probability of 0.003 indicate that there is a significant positive relationship Corporate Social Responsibility activities and Return on Sales.

\section{Conclusion and Recommendations}

Based on the findings of the study some conclusions are made. Corporate Social Responsibility is a veritable management strategy to enhancing corporate competitiveness of business in Nigeria. Firms that engaged in CSR gains improved business sales and returns on investment. Thus firms that fulfils extra social obligations that keeps capable of enhancing its corporate image will be better positioned to explore more market share and profitability, thus are likely to be more competitive. This supposes that corporate social responsibilities is not just a humanitarian service to the host communality as part of the firms' contribution at improving the environment and encouraging better life in the community, but equally a strategic "weapon" to improving corporate competitiveness. Following from the conclusions, the study recommends that firms should incorporate CSR obligations into its corporate strategic plans.

\section{References}

Abogun, S., Fagbemi, T. O. \& Uwuigbe, O. R. (2013). The impact of corporate social responsibility expendicture on Nigerian firm performance and firm value of Nigerian banks. Advances in Management, 12(1), 1 - 12. Retrieved from https://www.unilorin.edu.ng/publications/fagbemito/PAPER\%204.pdf.

Adeyemi, T. (2014). Corporate social responsibility and financial performance of quoted pharmaceutical firms in Nigeria. A dissertation submitted to the Postgraduate School Usmanu Danfodiyo University, Sokoto, Nigeria, in partial fulfilment of the requirements for the award of the Degree of Master Of Science (Accounting and Finance). Retrieved from http://dspace.udusok.edu.ng:8080/jspui/bitstream/123456789/439/1/ADEYEMI\%20TAIYE\%2 008211902018.pdf

Akindele, A. I. (2011). Corporate social responsibility: an organisational tool for survival in Nigeria. African Journal for the psychological study of social issues, 19(2), 10-15.

Ali, I., Rehman, K. U., Yilmaz, A.K., Nazir, S. \& Ali, J. F. (2010). Effects of corporate social responsibility on consumer retention in cellular industry of Pakistan. African Journal of Business Management, 4(4), 475-485.

Asamoah, E. S. (2013). The effect of corporate social responsibility on the competitiveness of firms in the mobile telecommunication industry in Ghana. Retrieved from https://www.vse.cz/polek/download.php?jnl=eam\&pdf=259.pdf.

Battaglia, M., Testa, F., Bianchi, L., Iraldo, F. \& Frey, M. (2014). Corporate social responsibility and competitiveness within SMEs of the fashion industry: Evidence from Italy and France. Sustainability, 6, 872-893.

Blowfield, M. \& Frynas, J. G. (2005). Setting New Agendas: Critical Perspectives on Corporate Social Responsibility in the Developing World. International Affairs, 81(3), 499-513. 
INTERNATIONAL JOURNAL OF ACADEMIC RESEARCH IN BUSINESS AND SOCIAL SCIENCES Vol. 9, No. 5, May, 2019, E-ISSN: 2222-6990 @ 2019 HRMARS

Brammer, S., Millington, A. \& Rayton, B. (2007). The contribution of corporate social responsibility to organizational commitment. International Journal of Human Resource Management, 18, 1701-1719.

Brundtland, G. H. (1987). Presentation of the report of the World Commission on Environment and Development to UNEP's 14th Governing Council Session. World Commission on Environment and Development, Nairobi.

Danko, D., Goldberg, J. S., Goldberg, S. R., \& Grant, R. (2008). Corporate Social Responsibility: The United States vs. Europe. The Journal of Corporate Accounting and Finance, September/October, 41-47.

Dawkins, J. (2004). Corporate responsibility: the communication challenge. Journal of Communication Challenge, 9(2), 108-119.

Deetz, S. (2003). Corporate governance, communication and getting social values into the decisional chain. Management Communication Quarterly, 16, 606-611.

Eze, O. R. \& Okoye, V. (2013). Impact of corporate social responsibility on the deposit money banks in Nigeria. Global Business and Economics Research Journal, 2 (3), 71 - 84.

Fauzi, H. (2008). The Determinants of the Relationship of Corporate Social Performance and Financial Performance. A Conceptual Framework: Issues in Social and Environmental Accounting Forthcoming. Retrieved from http://ssrn.com/abstract=1489824pp1-2.

Folajin, O. O., Ibitoye, O. T., \& Dunsin, A. T. (2014). Corporate Social Responsibility and Organizational Profitability: An Empirical Investigation of United Bank for Africa (UBA) Plc. International Journal of Academic Research in Business and Social Sciences, 4(8), 205 - 214 , Retrieved from http://hrmars.com/hrmars_papers/Corporate_Social_Responsibility_and_Organizational_Pro fitability_An_Empirical_Investigation_of_United_Bank_for_Africa_(UBA)_Plc.pdf.

Freeman, R. (1984). Strategic Management: A Stakeholder Approach. U.S.A: Pitman Freeman R (1984). Strategic Management: A Stakeholder Approach. U.S.A: Pitman

Friedman, M. (1970). The social responsibility of business is to increase its profits. New York Times Magazine, September 13, 33, 124, 126. Retrieved from www.colorado.edu/studentgroups/libertarians/issues/friedmansoc- resp-business.html.

Islam, K. (2012). Corporate Social Responsibility (CSR) and Issue to Corporate Financial Performance (CFP): An Empirical Evidence on Dhaka Stock Exchange (DSE) Listed Banking Companies in Bangladesh. European Journal of Business and Management, 4 (11), 11 - 33.

Maignan, I. \& Farrell, O. C. (2004). Corporate social responsibility and marketing: An integrative framework, Journal of the Academy of Marketing Science, 32(1), 3-19.

Malik, M. S., Ali, H. \& Ishfaq, A. (2015). Corporate Social Responsibility and Organizational Performance: Empirical Evidence from Banking Sector. Pakistan Journal of Commerce and Social Sciences, 9 (1), 241-247. Retrieved from http://www.jespk.net/publications/232.pdf.

McPeak, C. and Oianwen, D. D. (2011). Environmental Issues as a part of sustainability and how they impact financial performance. Journal of Global Business Issues. Burbank, 5(2), 49- 53.

Melé, D. (2008). CSR Four theories for a Necessary Practice. Oxford University Press Online document. Retrieved from http://insight.lese.edu/doc.aspx?id=889\&ar=17. 
INTERNATIONAL JOURNAL OF ACADEMIC RESEARCH IN BUSINESS AND SOCIAL SCIENCES

Vol. 9, No. 5, May, 2019, E-ISSN: 2222-6990 @ 2019 HRMARS

Nasieku, T., Togun, O. R. \& Olubunmi, E. M. (2014). Corporate Social Responsibility and Organizational Performance: A Theoretical Review. International Journal of Humanities Social Sciences and Education, 1(12), 106-114. Retrieved from https://www.arcjournals.org/pdfs/ijhsse/v1-i12/14.pdf.

Nicolau, J. L. (2008). Corporate Social Responsibility, Worth-Creating Activities. Annals of Tourism Research, 35(4), 990-1006.

Odetayo, T. A., Adeyemi, A. Z. \& Sajuyigbe, A. S. (2014). Impact of Corporate Social Responsibility on Profitability of Nigeria Banks. International Journal of Academic Research in Business and Social Sciences, 4(8), 252 - 263. Retrieved from http://hrmars.com/hrmars_papers/Impact_of_Corporate_Social_Responsibility_on_Profitabil ity_of_Nigeria_Banks.pdf.

Ojo, O. (2008). Appraisal of the practice of social responsibility by business organizations in Nigeria. Covenant University, Ota, Nigeria. Pp. 1-11.

Porter, M. E. \& Kramer, M. (2006). The link between competitive advantage and corporate social responsibility. Harvard Business Review, 84, 78-92.

Rapti, E. \& Medda, F. (2012).Corporate Social Responsibility and Financial Performance in the Airport Industry. Retrieved from www.ucl.ac.uk/qaser/pdf/publications/csr_airports.pdf.

Shehu, A. (2013). The influence of corporate social responsibility on profit after tax of some selected deposit money banks in Nigeria. Educational Research, 4(10), 722-732.

Stanwick, P. A. \& Stanwick, S. D. (1998). The Relationship between Corporate Social Performance and Organisational Size, Financial Performance, and Environmental Performance: An Empirical Examination. Journal of Business Ethics, 17(2), 195- 204.

Tilt, C. A. (1994). The Influence of External Pressure Groups on Corporate Social Disclosure: Some Empirical Evidence. Accounting, Auditing and Accountability Journal, 7, 47 - 59. 